\title{
Diversity of freshwater algae in some selected sites in river Naguman district Charsadda, Khyber Pakhtunkhwa, Pakistan
}

Sher Wali ${ }^{*}$, Tabassum Yaseen ${ }^{2}$, Samin Jan ${ }^{1}$, Izhar Ahmad ${ }^{1}$, Muhammad Saleem Khan ${ }^{1}$, Fazli Rahim ${ }^{2}$ and Noman ${ }^{2}$

1. Department of Botany, Islamia College, Peshawar, Khyber Pakhtunkhwa-Pakistan

2. Department of Botany, Bacha Khan University, Charsadda, Khyber Pakhtunkhwa-Pakistan

*Corresponding author's email: sherwali@icp.edu.pk

Citation

Sher Wali, Tabassum Yaseen, Samin Jan, Izhar Ahmad, Muhammad Saleem Khan, Fazli Rahim and Noman. Diversity of freshwater algae in some selected sites in river Naguman district Charsadda, Khyber Pakhtunkhwa, Pakistan. Pure and Applied Biology. Vol. 6, Issue 1, pp180-189. http://dx.doi.org/10.19045/bspab.2017.60012

\begin{tabular}{llll}
\hline \hline Received: 21/11/2016 & Revised: 26/01/2017 & Accepted: 31/01/2017 & Online First: 03/02/2017 \\
\hline
\end{tabular}

Abstract

In the current research work algal collection was made at different sites of River Naguman near its joining point with Sardaryab. Various sites expected to have rich algal flora across an area of $10 \mathrm{Km}^{2}$ were selected to obtain algal samples. A total of 38 species belonging to 16 genera of freshwater algae were collected and identified. Keys were constructed both at generic and specific levels for identifications and description. Out of these 16 genera Chlorophyta contributed 50\%, Bacillariophyta 25\%, Charophyta $6.25 \%$, Xanthophyta $12.5 \%$ and Cyanophyta contributed $6.25 \%$ genera. Chlorophyceae were the most common represented by $60.53 \%$ species, Bacillariophyceae were next with $18.42 \%$ species, Charophyceae by $5.26 \%$, Xanthophyceae by $5.26 \%$ and Cyanophyceae were represented by $10.53 \%$ species. The most dominant genus in terms of species was Spirogyra with eight species 21.1\%. Cladophora and Oscillatoria were next dominants with $10.5 \%$ species. Rhizoclonium, Zygnema and Nitzschia were each represented by $7.9 \%$. Closterium, Diatoma and Chara each contributed $5.3 \%$ species. All the remaining genera including Ulothrix, Mougeotia, Desmidium, Cyclotella, Tabellaria, Ophiocytium and Vaucheria each contributed $2.6 \%$ species.

Keywords: River Naguman; Algae; Chlorophyta; Bacillariophyta; Charophyta; Xanthophyta; Cyanophyta

\section{Introduction}

Algal collection was done in some selected sites in River Naguman, District Charsadda. District Charsadda lies between 34-03' and 34-38' north latitudes and 71-28' and 71-53' east longitudes. Charsadda is located in the west of Khyber Pakhtunkhwa and is bounded by Malakand District on the north, district Mardan on the east, Nowshera and Peshawar districts on the south and Mohmand Agency of the Federally Administered Tribal Areas on the west. The district covers an area of 996 square kilometers. 
Algae are chlorophyll bearing organisms which are thalliod in nature. Algae are divided into different groups on the basis of characteristic pigments and resulting colours of thalli. Brown algae are the largest type of algae. The brown or yellow-brown colour is due to fucoxanthin. Red algae often have brilliant colours due to phycoerythrin and phycocyanin. Green algae contain chlorophyll-a and chlorophyll-b in the same proportion as in higher plants [1]. Many species of algae are involved in algal blooms and these species change over time based on temperature, light, nutrients, and other factors [2]. According to [3] attached algae may also live as epiphytes on other living organisms including larger attached algae, large planktonic colonial algae and higher plants. Fresh algae, frozen or heat killed algae, algae powder and baker's yeast are some of the food sources that have been exploited for the culture of rotifers [4]. Freshwater harmful algal blooms (HABs) can have serious ecological, toxicological and physiological effects on aquatic and terrestrial biota. Microalgae are unique photosynthetic microorganisms which have the ability to convert solar energy into biomass. Global distribution of toxic cyanobacterial incidents reveals to have increased which may be related to the global climate changes [5].

\section{Materials and methods}

Fresh algal samples were collected from some selected sites in River Naguman in a $10 \mathrm{Km}^{2}$ area selected as the water runs slowly in this area and great algal populations are present. Samples were selected in five sites. Water $\mathrm{pH}$ recorded via electric $\mathrm{pH}$ meter at different sites ranged from 6.70-7.5 while temperature of water ranged from $15-35{ }^{0} \mathrm{C}$. The samples were collected in spring and summer of the year 2015. These samples were collected from running water, shallow water and standing water [6] in order to get a complete profile of free floating and attached algal forms. Sampling was also done from the bottom of the stream and also from aquatic plants. Five samples were collected from each site. The samples were collected with the help of knife and stored in polythene bags. The samples were analyzed and characterized in the laboratory of Bacha Khan University Charsadda in polythene bags. Algae samples were preserved by storing in glass bottles with $4 \%$ formalin. To visualize and characterize algae a portion of the specimen was mounted on the glass slides covered by cover slips and observed under light microscope using different magnifications i.e. $10 \mathrm{X}, 40 \mathrm{X}$ and 100X. Plates of each algal specimen were made by capturing photographs through a digital camera from the respective slide under the highest (100X) power of the microscope; also taken from [7]. Algal identification and characterization were achieved with the help of Prescott's manual and Tiffany \& Britton $[6,7]$.

\section{Aim of the study}

The aim of the current research work was to identify and characterize various forms of freshwater algae collected from different sites in River Naguman.

\section{Results and discussion}

Algae are autotrophic organisms, constitute an important group of thallophyta, so it was desired to work out the diversity of freshwater algae of district Charsadda. A taxonomic study was carried out for the identification of Algae of the research area on the basis of their cytological and morphological features. River Naguman has rich algal flora. Algae have remarkable importance for life on earth surface. Algae play a basic role in different food chains as they are primary producers in almost all types of ecosystems. Algal members are adding fresh oxygen to the atmosphere regularly, contaminated by animals adding $\mathrm{CO}_{2}$. They directly or indirectly serve as food for fish and other aquatic animals 
important to man. Freshwater algae are known to produce a large number of toxic, Noxious and bioactive metabolites, thus rendering it difficult to select one specific test to quantify environmental effects.

In present study 38 species belonging to 16 genera and 5 classes were identified from different freshwater habitats of River Naguman district Charsadda. In the research work 16 Genera with 38 belonged to 5 classes i.e. Chlorophyta, Bacillariophyta, Charophyta, Xanthophyta and Cyanophyta.

Table 1. Percentage of different classes of freshwater algae of district Charsadda

\begin{tabular}{|l|c|c|c|}
\hline Class & No. of genera & No. of Species & Relative Representation \\
\hline Chlorophyceae & 8 & 23 & $60.53 \%$ \\
\hline Bacillariophyceae & 4 & 7 & $18.42 \%$ \\
\hline Charophyceae & 1 & 2 & $5.26 \%$ \\
\hline Xanthophyceae & 2 & 2 & $5.26 \%$ \\
\hline Cyanophyceae & 1 & 4 & $10.53 \%$ \\
\hline
\end{tabular}

Major class was found to be Chlorophyceae (1 order Conjugales (8) sp., Siphonales sp. (1), Zygnematales (1) sp., Cladophorales (4) sp. species of order Conjugales on plate (18) result is agreed with Sarim \& Zaman [8] because this class previously identified by [9] carried out an extensive study and reported 89 species belonging to 31, genera of Chlorophyceae, Bacillariophyceae, Xanthophyceae and Cyanophyceae, from District Charsadda (Figure 1). Cladophorales (4) sp. Plate no. 4 so our result agree with [8] who previously reported member of this class from Charssada previously this class also reported [10] from India. Siphonales sp. (1), Zygnematales (4) sp. on plate no. 5, 6 and 8 previously this class reported by Silvia Alfinito 2011 from Africa and Shameel reported from various areas of Azad Kashmir and KPK.

Charophyceae one genera and three species order Charales sp. on plate no. 5; so the result is agreed with [11, 12] previously reported Chara species from various freshwater habitat of Pakistan.
The most frequent genus in term of species was Spirogyra with 8 species. Cladophora and Oscillatoria were next dominants with 4 species each. Rhizoclonium, Zygnema and Nitzschia were each represented by 3 species. Closterium, Diatoma and Chara each contributed 2 species. All the remaining genera including Ulothrix, Mougeotia, Desmidium, Cyclotella, Tabellaria, Ophiocytium and Vaucheria each contributed a single species (Table 1).
Bacillariophyceae in our research is represented by the species of Diatoma, Nitzschia, Cyclotella and Tabellaria on plate no. 9, 10 and 11 (Figure 2). The results agreed to Sarim and Zaman because this class previously identified by Sarim \& Zaman (2005), carried out an extensive study Chrysophyceae from District Charsadda. Similar observations were made in the previous studies at Karachi [13, 14]. During the present study the species were found observed in Unicellular, unbranched filamentous, colonial, branched filamentous, pseudo filamentous and mesh like thallus \& irregular forms. Seasonal variation of freshwater algae was also noticed, generally green \& blue green algae were studied which breed in summer and spring season, but in summer they also survive. Water temperature is important, as the temperature increases the dissolved oxygen content decrease in water due to increase metabolism and respiration. High temperature has a direct effect on growth of algal species and communities and aquatic life. The Dissolved oxygen content of the 
freshwater dependent on several factors i.e., water movement, pollution, temperature of water, addition of freshwater from other sources, production of oxygen by plants and its consumption by plants, animals and bacteria. In summer, the temperature was high up to $38^{\circ} \mathrm{C}$ tremendous Sunlight and sluggish water was the most favorable environment for growth of algae. The rate of reproduction is very rapid of those species that reproduced in summer and rainy season and created a heavy mass on the surface of water. Their growth was most frequent in the aquatic medium especially in planktonic state as compared to the terrestrial environment.

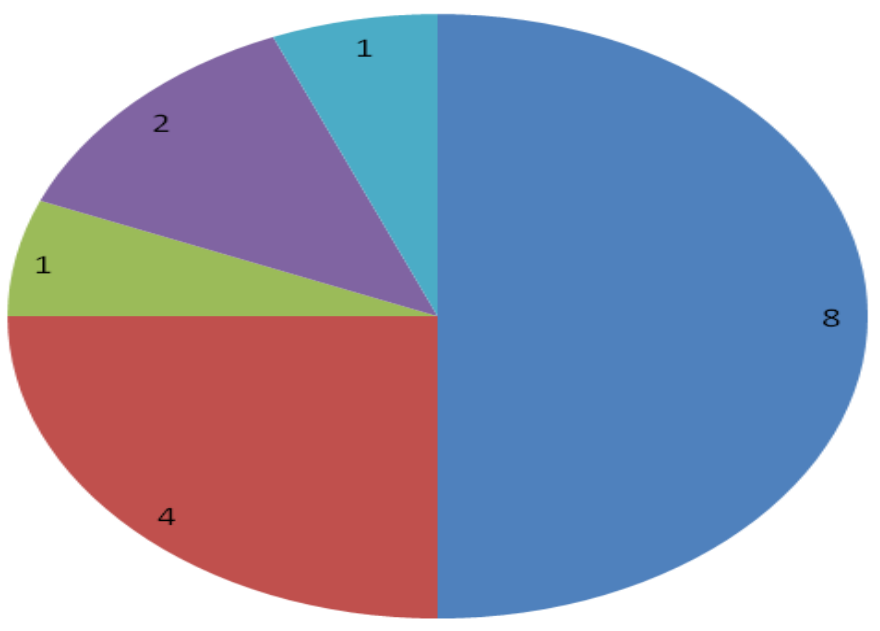

- Chlorophyceae

- Bacillariophyceae

- Charophyceae

- Xanthophyceae

- Cyanophyceae

Figure 1. Showing contribution of genera and species by each class of algae

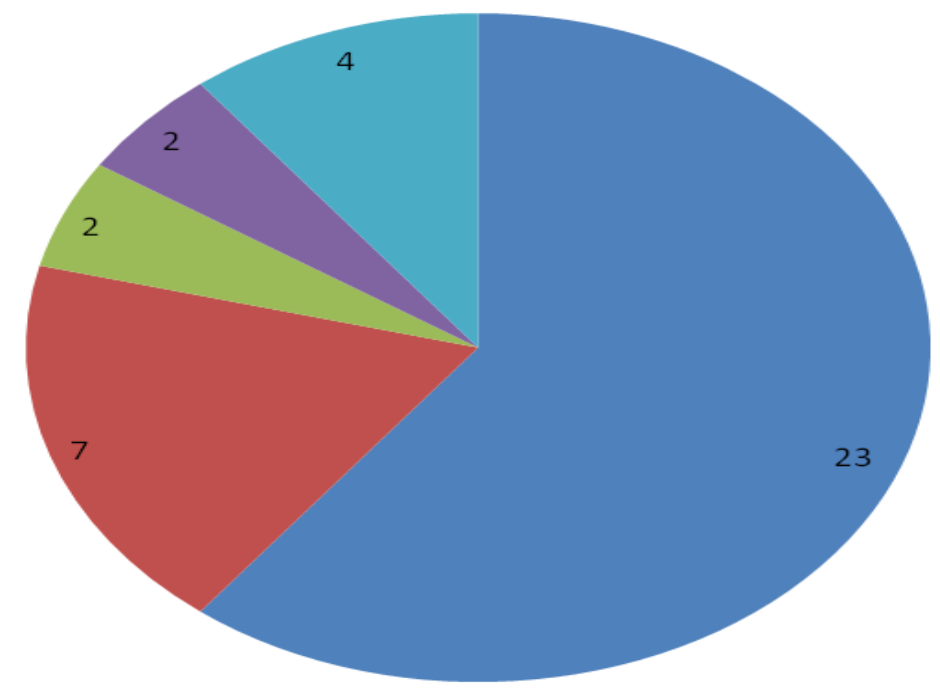

Chlorophyceae

- Bacillariophyceae

Charophyceae

- Xanthophyceae

- Cyanophyceae

Figure 2. Showing \% contribution of species by each class of algae 

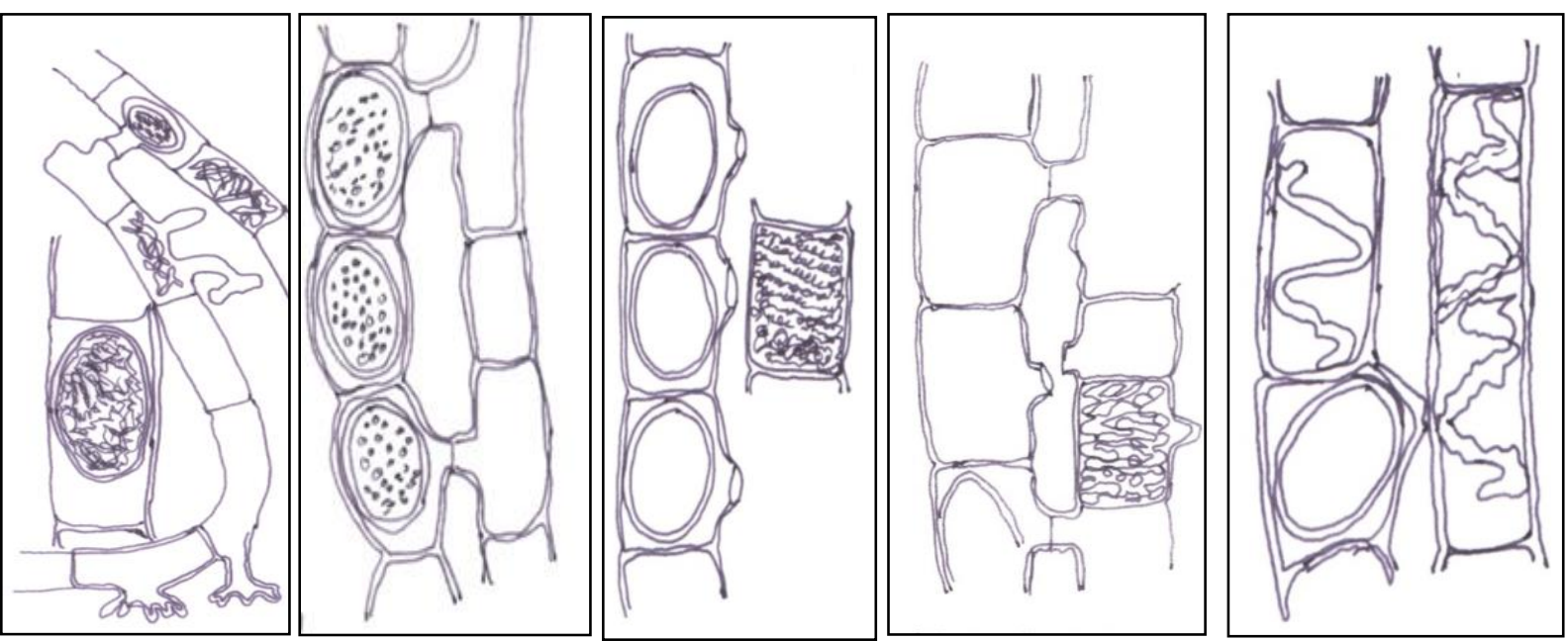

Plate 1. S. rhizobrachialis Plate 2. S. aequinoctialis Plate 3. S. crassa Plate 4. S. ellipsopora Plate 5: S. condensata
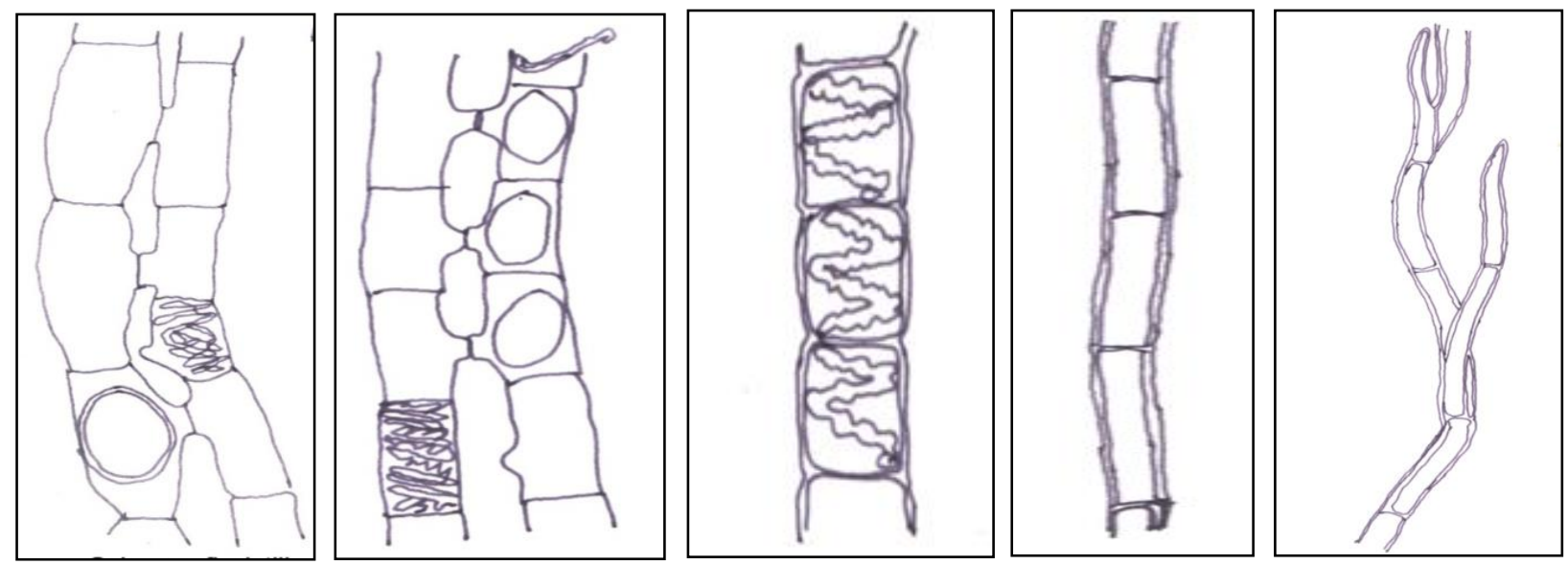

Plate 6. S. fluviatilis Plate 7. S. fuelleboprnei Plate 8. S. daedaleoides Plate 9. R. hieroglyphicum Plate 10 R. fontanum
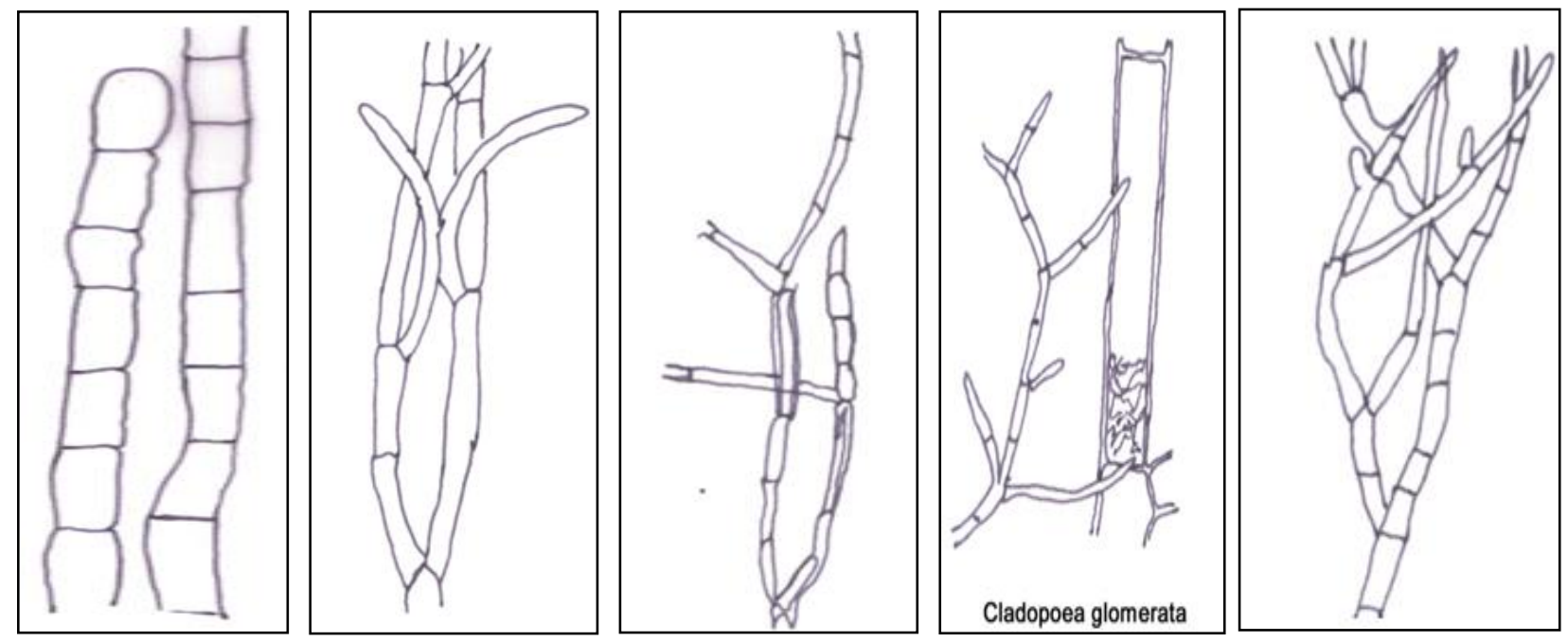

Plate 11. R. hookeri Plate 12. C. oligoclona Plate 13. C. fracta Plate 14.C. glomerata

Plate 15. C. crispate 
Wali et al.
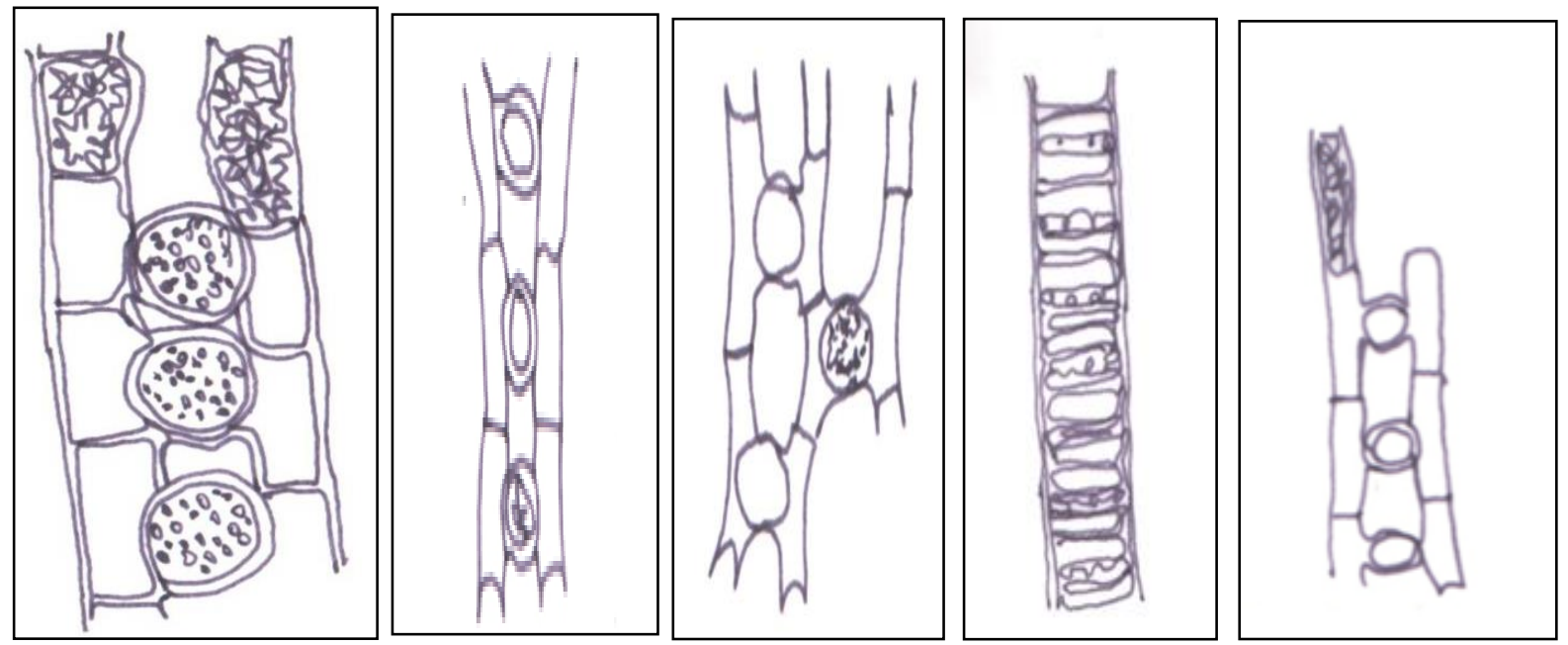

Plate 16. Z. pectinatum Plate 17. Z. decussatum Plate 18. Z. synadelphum Plate 19. U. zonata Plate 20. M. robusta
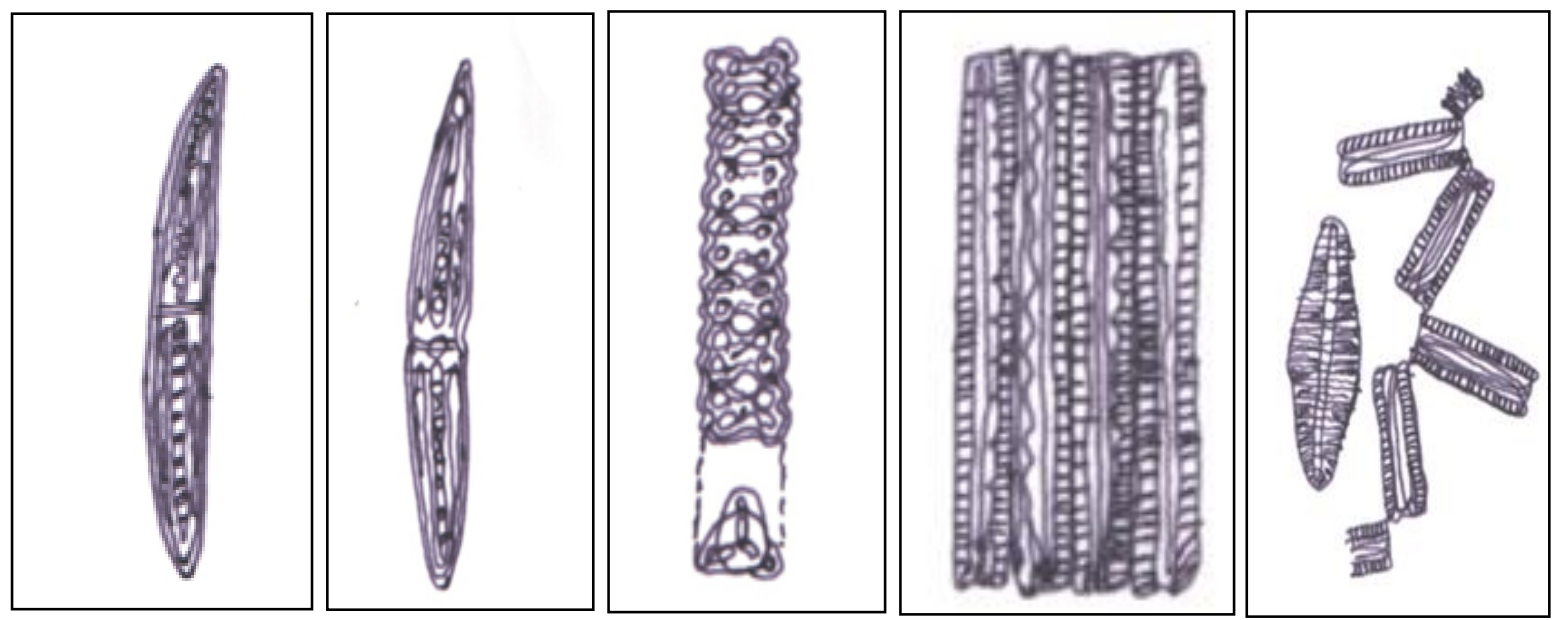

Plate 21. C. acersoum Plate 22. C. lanceolatum Plate 23. D. aptogonum Plate 24. D. anceps Plate 25. D. vulgare
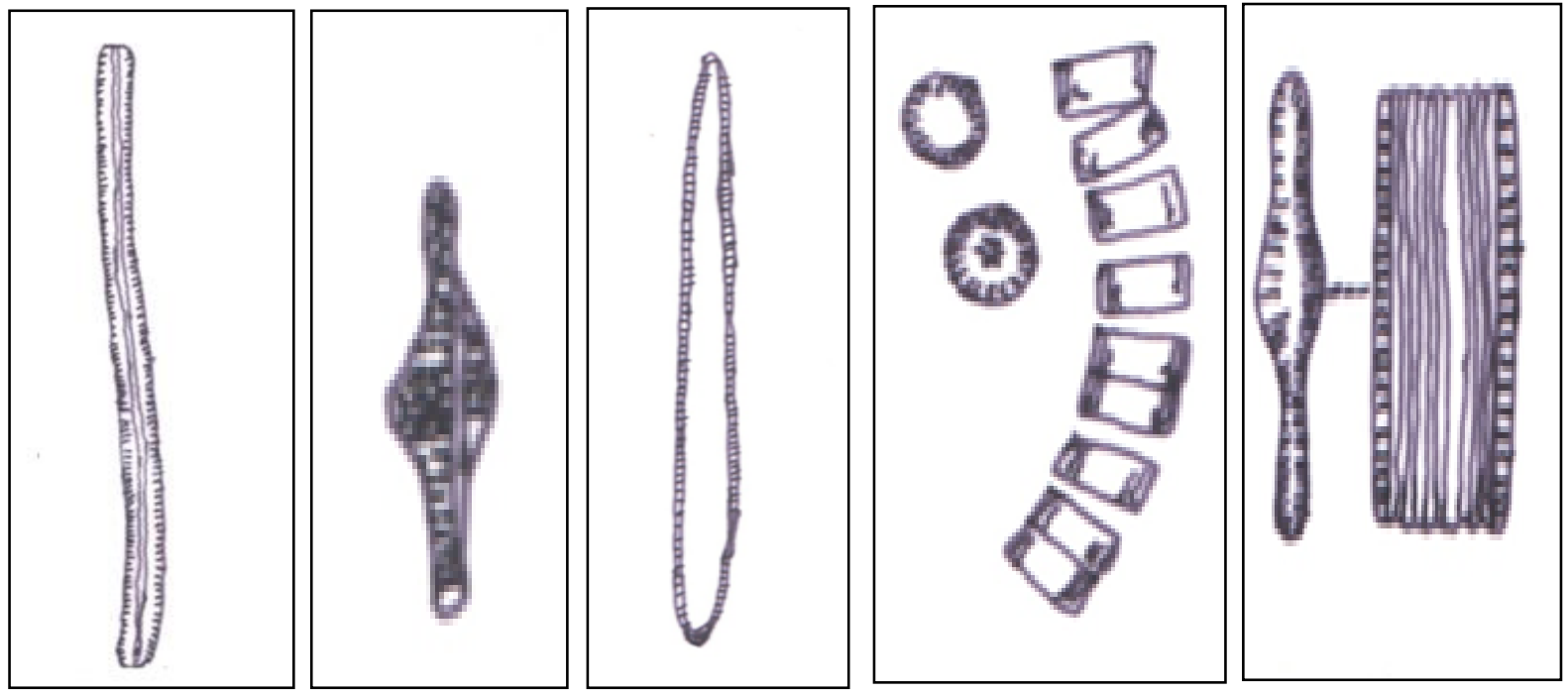

Plate 26. N. vermicularis Plate 27. N. sinuata Plate 28. N. linearis Plate 29. C. glomerata Plate 30. T. flocculosa 


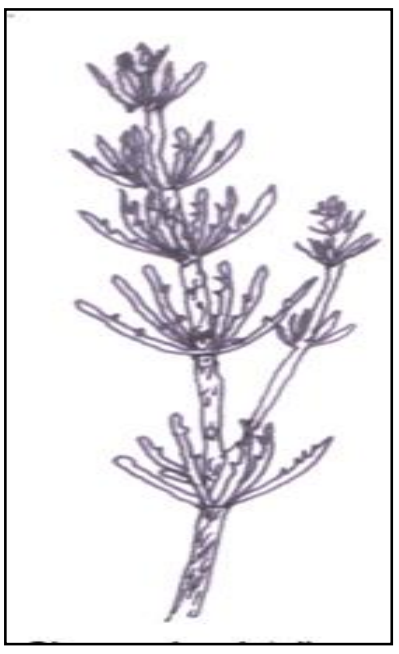

Plate 31. C. schweinitzii

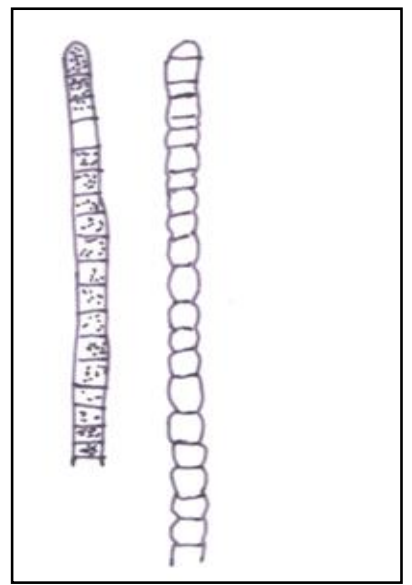

Plate 35: O. tenuis

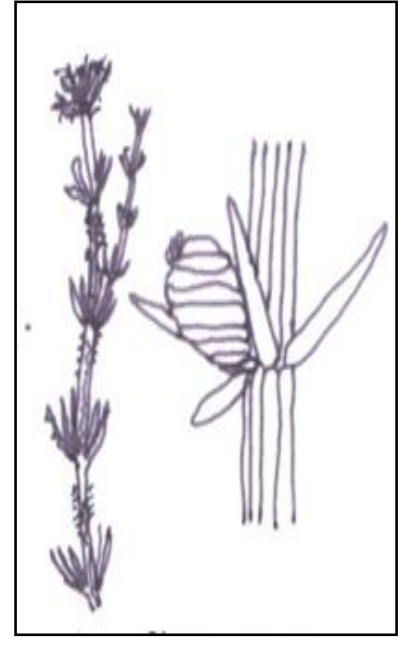

Plate 32. C. conescens

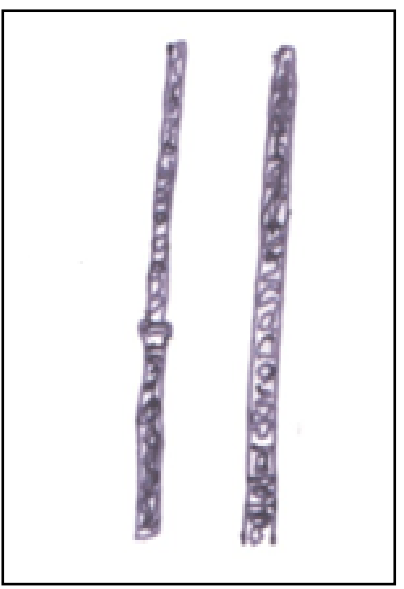

Plate 36: $O$. prolifica

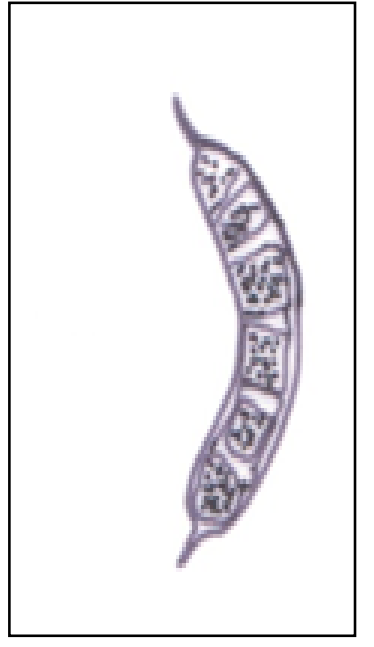

Plate 33. O. capitatum

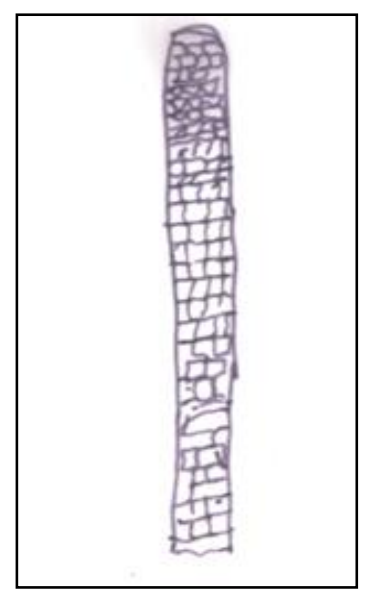

Plate 37: $O$. bornetti

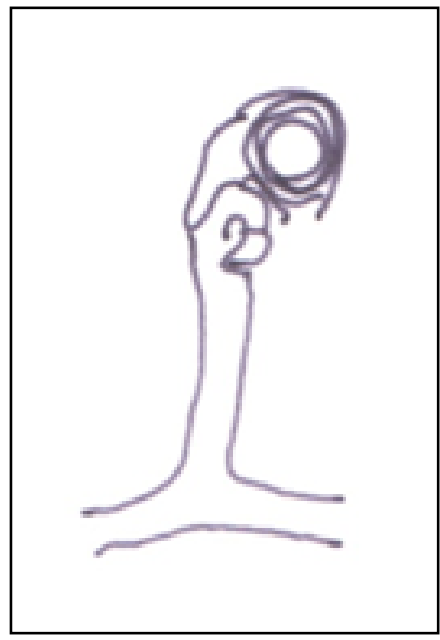

Plate 34. V. terrestris

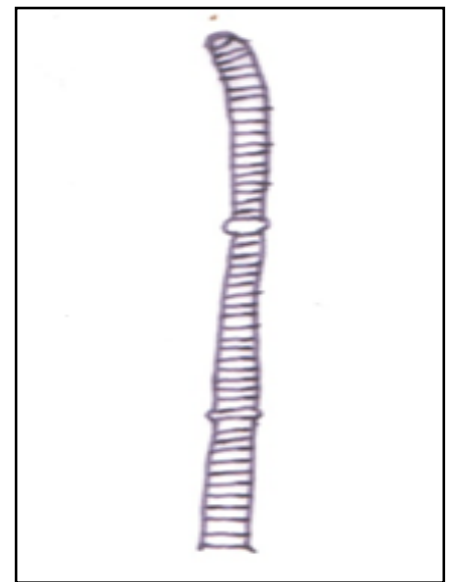

Plate 38: $O$. anguina

\section{Taxonomic Description}

\section{Class: Chlorophyceae}

\section{A. Spirogyra Link (Plat 1-8)}

\section{Key to the species}

1. Zygospore averaging larger $38-62 \mu$ in diameter, median spore's wall irregularly reticulate filaments of rather stout cell 40-59in diameter.

S. rhizobrachialis

2. Vegetative cells $23-25 \mu$ in diameter

S. aequinoctialis

3. Vegetative cell 140-165 $\mu$ in diameter spores compressed S. crassa

4. Vegetative cell $125-150 \mu$ in diameter S. ellipsopora

5. Vegetative cell $48-62 \mu$ in diameter S. condensata

6. Fertile cell inflated S. fluviatilis

7. Vegetative cell $40-44 \mu$ in diameter chloroplast making 1-2 turn S. fuelleboprnei

8. Spore ellipsoid $35-44 \mu$ in diameter S. daedaleoides

B. Rhizoclonium Kuetzing (Plat 9-11)

Key to the species

1. Filaments (10)-25-35-(52) $\mu$ in diameter; wall up to $2 \mu$ thick R. hieroglyphicum 
2. Filaments $12-22 \mu$ in diameter; branches simple

.R. fontanum

3. Filaments $60-64-103 \mu$ in diameter, $2^{\text {nd }}$ order branches frequently present...........R. hookeri C. Cladopora Kuetzing (Plat 12-15)

Key to species

1. Vegetative cells $45-55 \mu$ in diameter .............................................. . oligoclona

2. Vegetative cells 60-120 $\mu$ in diamet................................................... fracta

3. Vegetative cells 75-100 $\mu$ in diameter without bristles like outgrowths......... C. glomerata

4. Vegetative cells 40- $75 \mu$ in diameter ..................................................... crispata

D. Zygnema (Plat 16-18)

Key to the species

1. Vegetative cells $30-40 \mu$ in diameter........................................... pectinatum

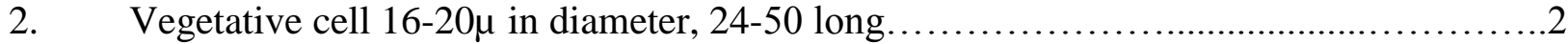

2. Chloroplast with 2 pyrenoids.......................................... decussatum

4. Vegetative cells $17-21 \mu$ in diameter fertile cells is not inflated................ synadelphum

E. Ulothrix Kuetzing (Plat 19)

Key to the species

1. Filaments $20 \mu$ or more in diameter, wall thick

..U. zonata

F. Mougeotia (G.A Agardh) Wittrock (Plat 20)

Key to the species

1. Vegetative cell $25-33 \mu$ in diameter

M. robusta

G. Closterium (Plat 21-22)

Key to Species

1. Cell tapering gradually to subacute or rounded truncate apices

C. acersoum

2. Apices acutely rounded

C. lanceolatum

H. Desmidium (Plat 23)

Key to Species

1. Cell apices with broad depression

D. aptogonum

II. Class: Bacillariophyceae

I. Diatoma (Plat 24-25)

Key to the species

1. Cells united into zigzag chains 1

1. Valves capitates, narrowly linear. D. anceps

2. Cells 10-13 $\mu$ long D. vulgare

J. Nitzschia (Plat 26-28)

Key to Species

1. Valves 5-7 $\mu$ broad

N. vermicularis

2. Valve margins undulate N. sinuate

3. Valves linear, 70-180 $\mu$ long. N. linearis

K. Cyclotella (Plat 29)

Key to the Species

1. 8-chain loose with space between cells

C. glomerata.

L. Tabellaria (Plat 30)

Key to the species

1. Cells with the numerous longitudinal septa................................T. flocculosa

III. Class: Charophyceae

M. Chara Toiseleur-Deslongchamps (Plat 31-32) 
Key to the Species

1. Bracket about the oogonium as longer than the mature fruit. ............... Schweinitzii

2. Cortication haplostichous................................................... conescens

IV. Class: Xanthophyceae

N. Ophiocytium (Plat 33)

Key to the species

1. Cells with polar spines with at each pole

O. capitatum

O. Vaucheria De Condolle (Plat 34)

Key to the species

1. Oogonia $60-103 \mu$ in diameter, $85-211 \mu$ long without a pedicle.................. terrestris

V. Class: Cyanophyceae

P. Oscillatoria Vaucher (Plat 35-38)

Key to the species

1. Cells with rows of granules at the cross walls..................................... tenuis

2. Apical cells with flattened calyptra.......................................... prolifica

3. Cells almost colourless with large conpicous alveoli or vacuoles................... bornetti

4. Trichomes bent or hooked at the apex, forming a plant mass..................... anguina

\section{Conclusion}

The current study revealed that River Naguman has great Algal diversity. Species of the five major classes of algae are present abundantly. The algae present in the area may be investigated for the presence various biochemicals and secondary metabolites.

Authors' contributions

Conceived and designed the experiments: $S$ Wali, Performed the experiments: T Yaseen, S Jan \& I Ahmad, Analyzed the data: F Rahim \& Noman, Contributed reagents/ materials/ analysis tools: MS Khan, Wrote the paper: $\mathrm{S}$ Wali \& $\mathrm{T}$ Yaseen.

\section{References}

1. Domínguez H (2013). Algae as a source of biologically active ingredients for the formulation of functional foods and nutraceuticals. In: Domínguez H. (ed.), Functional ingredients from algae for foods and nutraceuticals, Cambridge: Woodhead Publishing. p.33.

2. Ali A, Shinwari ZK \& Sarim FM (2010). Contribution to the algal flora (Chlorophyta) of freshwaters of district Swat. N.W.F.P., Pakistan. Pak J Bot 42(5): 3457-3462.

3. Suresh B, Manjappa S \& Puttaiah BT (2011). Seasonal variation of phytoplankton in Tungabhadra River near Harihar- Karnataka. Research Journal of Biological Sciences 6(2): 65-68p.

4. Fujii M, Rose AL \& Waite TD (2011). Iron uptake by toxic and nontoxic strains of Microcystis aeruginosa. Appl Environ Microbiol 77(19): 7068-7071.

5. Neilan BA, Pearson LA, Muenchhoff J, Moffitt MC \& Dittmann E (2013). Environmental conditions that Influence Toxin Biosynthesis in Cyanobacteria. Environmental Microbiology 15(5): 1239-1253.

6. Tiffany LH \& Britton ME. (1952). The Algae of Illinois. Univ. Chicago Press, Chicago. pp. 407.

7. Prescott GW (1978). How to Know the Freshwater Algae. W.C. Brown Co., Dubuque, Iowa pp. 283-295.

8. Sarim FM \& Zaman A (2005). Some freshwater algae of District Charsadda NWFP, Pakistan. PUTAJ 12: 5-10.

9. Nawaz A \& Sarim FM (2004). The freshwater algae of Swat River. Peshawar Univ. Teach Assoc J 10: 181-183.

10. Mishra BP \& Tripathi BD (2002). Changes in algal community structure and primary productivity of river Ganga as influenced by sewage discharge. 
Ecology Environment and conservation 6: 279-287.

11. Zaman A \& Hussain F (2006). Impact of water quality on the algal diversity during winter season in Peshawar valley, Pakistan. Int J Phycol Phcochem 2(1): 77-86.

12. Ali ST, Hasan M \& Shameel M (2008). Occurrence of the families Naviculaceae and Surirellaceae (Bacillariophyta) in the Punjab and N.W.F.P, Pakistan. Pak J Bot 4(5): 2143-2148.
13. Leghari SM (2001). Some fresh water green Filamentous Algae (Chlorophyta) and Dinobryon cylindricum (Chrysophyta) from Lakes and Riverin Ponds of Sindh, Pakistan. Online Journal of Boiological Sciences 1(3): 145-149.

14. Leghari MK, Butt F \& Rehman S (2007). Fresh water algae from Bunkhurme Mirpur, Azad Kashmir. Int J Phycal Phycochem 3(1): 29-36. 